\title{
Correlation Analysis of Toxic Metals Distribution and Pollution Indices in Soil, Beans and Maize Samples of Kano State, Nigeria
}

\author{
A. J. Alhassan ${ }^{1}{ }^{*}$, I. U. Muhammad ${ }^{2}$, M. S. Sule ${ }^{1}$, M. A. Dangambo ${ }^{1}$, \\ A. M. Gadanya ${ }^{1}$, Y. Umar ${ }^{3}$, Misbahu A. Dangambo ${ }^{4}$, A. Mohammed ${ }^{5}$ \\ and M. Syed ${ }^{4}$ \\ ${ }^{1}$ Department of Biochemistry, Faculty of Basic Science, Bayero University, P.M.B. 3011, Kano, \\ Nigeria. \\ ${ }^{2}$ Department of Medical Biochemistry, College of Medical Sciences, Yobe State University, \\ P.M.B. 1144, Damaturu, Yobe State, Nigeria. \\ ${ }^{3}$ Department of Science Laboratory Technology, Federal College of Agricultural Produce Technology, \\ Hotoro, Kano, Nigeria. \\ ${ }^{4}$ Department of Geography and GIS, College of Environmental Studies, Barnawa, Kaduna \\ Polytechnics, Kaduna State, Nigeria. \\ ${ }^{5}$ Department of Biochemistry, College of Medical Sciences, Abubakar Tafawa Balewa University, \\ P.M.B. 0248, Bauchi, Nigeria.

\section{Authors' contributions} \\ This work was carried out in collaboration among all authors. Authors AJA, IUM and YU designed the \\ study, performed the statistical analysis, wrote the protocol and wrote the first draft of the manuscript. \\ Authors MSS, M. A. Dangambo, AMG, Misbahu A. Dangambo and MS managed the analyses of the \\ study. Author MSS managed the literature searches. All authors read and approved the final \\ manuscript. \\ Article Information \\ DOI: $10.9734 / A R R B / 2019 / v 32 i 330086$ \\ Editor(s): \\ (1) Dr. Msafiri Yusuph Mkonda, Lecturer, Sokoine University of Agriculture, Tanzania. \\ (2) Dr. Manikant Tripathi, Department of Microbiology, Dr. Ram Manohar Lohia Avadh University, India \\ (3) Dr. George Perry, Dean and Professor of Biology, University of Texas at San Antonio, USA. \\ Reviewers: \\ (1) Luiz Di Souza, University of the State of Rio Grande of Norte, Brasil. \\ (2) Gunnar Bengtsson, Sweden. \\ (3) Kaywood Elijah Leizou, Niger Delta University, Nigeria \\ Complete Peer review History: http://www.sdiarticle3.com/review-history/47950
}




\section{ABSTRACT}

Correlational study and evaluation of pollution indices of toxic metals distribution in soil and crops of a population are imperative for assessing the risk of chronic diseases associated with these metals. Correlational analysis for the distribution of; lead $(\mathrm{Pb})$, cadmium $(\mathrm{Cd})$, chromium $(\mathrm{Cr})$ and mercury $(\mathrm{Hg})$ in soil $(\mathrm{S})$, bean $(\mathrm{B})$ and maize $(\mathrm{M})$ was conducted around Bunkure (BKR), Danbatta (DBT), Gwarzo (GRZ), Ungogo (UGG) and Wudil (WDL) as sampling zones around Kano State, Nigeria. The samples were collected from farm harvests in each of the sampling zones. The metal concentration was determined using atomic absorption spectrometry (AAS). Results in $\mathrm{mg} / \mathrm{kg}$ across the local governments indicate respective ranges for $\mathrm{Hg}, \mathrm{Pb}, \mathrm{Cd}$, and $\mathrm{Cr}$ of; $0.33-3.13,0.14-0.84$, $0.02-0.05$ and $0.01-0.49$ in soil, $0.04-4.23,0.06-0.23,0.02-0.04$ and $0.00-0.10$ in maize and $0.20-$ $4.23,0.16-0.19,0.03-0.04$ and $0.00-0.03$ in beans. Although with the exception of mercury, the ranges of the toxic metals are within the tolerable range set by International Standard Tolerable Limits and European Regulatory Standard. Potential hazard may be speculated because the detected levels are on higher tolerable ranges. A higher level of mercury in almost all the samples indicates potential hazards associated with human activities in those areas. A strong positive correlation between soils samples in respect to the level of some of the toxic metal may suggest a common nature of the soil, while the negative correlation may be due to variation in agrochemicals in-use. For the pollution load index, Wudil had the highest soil pollution load index for $\mathrm{Hg}(3.13 \pm$ $0.16), \mathrm{Cd}\left(1.6 \times 10^{-2} \pm 0.01\right)$ and $\mathrm{Cr}\left(4.9 \times 10^{-3} \pm 0.01\right)$, while Ungogo had the highest pollution load for $\mathrm{Pb}$. Also, all grains within the study zones exhibited a positive transfer factor, except $\mathrm{Cr}$ in Bunkure, Danbatta and Gwarzo. It may be concluded that crops grown in those areas may bioaccumulate some of these toxic metals, thereby incorporating them into the food chain, hence potential health risk.

Keywords: Toxic metals; soil; farm produce; correlation; distribution; pollution index; Kano-local government areas.

\section{INTRODUCTION}

Toxic metals are those metals having a higher atomic number, associated with little or no biochemical functions. However; they have many industrial and agricultural applications [1] and are relatively high-density metallic elements with potential toxicity at low concentration [2]. According to $\mathrm{WHO}$, toxic metals occur in a trace amount and are at least five times denser than water, They are stable and persistent in environmental samples, hence bioaccumulate to pass up via food chain to humans [3]. According to Alhassan [4], sources of heavy metals are varied and include natural sources and all human activities, with the possibility of polluting the environment. In another perspective, environmental toxic metals are due to direct deposition from mining activities, industrial processes as well as wastewater from domestic processes, in addition to agricultural practices [5]. Heavy metals contamination to agricultural soils could be through a variety of sources among which is the land application of biosolids, fertilizers, livestock manure, agrochemicals (Pesticides), irrigation activities and an atmospheric droplet [6]. Worthy consideration is the accumulation of these metals in agricultural soils and possible negative impacts on soil fertility and large potential accumulation in crops for possible incorporation to human food chains [7]. Unlike the inorganic, the organic (alkylated) forms are readily taken up by body tissues and can be retained for a considerable length of time due to their lipid solubility [8]. The tissue penetrating power of organometals crowns them more toxic to humans than the inorganic form [9].

Human exposure to soil accumulated toxic metal may be chronic via food chain transfer or acute by direct ingestion or dermal contact. The former maybe associated with; mental lapses, kidney, liver, lung and gastrointestinal tract abnormalities, central nervous insufficiency, lower energy levels, damage to blood compositions, kidneys, and other vital organs [7]. Long term exposure to low dose may result in slowly progressing physical, muscular, and neurological degenerative processes that mimic Alzheimer's disease, Parkinson's disease, muscular dystrophy, and multiple Sclerosis [10]. Allergies are not uncommon and repeated longterm contact with some metals or their compounds may even cause cancer. The letter depends on the degree to which a system, 
tissue, organ or cell is affected by a heavy metal type and the individual's degree of exposure [11].

Mercury combines with other elements to form organic and inorganic mercury compounds. Metallic mercury used to produce chlorine gas, caustic soda, in thermometers and dental fillings, switches, light bulbs, and batteries, including coal-burning power plants are the largest humancaused source of mercury emissions to the air in the United States. Mercury in soil and water is converted by microorganisms to methyl mercury, a bioaccumulating toxin [12]. The EPA reported that mercuric chloride and methyl mercury are possible human carcinogens and nervous system is very sensitive to all forms of mercury. Exposure to high levels can permanently damage the brain, kidneys, and developing fetuses. Effects on brain functioning may result in irritability, shyness, tremors, changes in vision or hearing, and memory problems. Short-term exposure to high levels of metallic mercury may cause lung damage, nausea, vomiting, diarrhea, increases in blood pressure or heart rate, skin rashes, and eye irritation [13].

Exposure to high lead levels can severely damage the brain and kidneys and ultimately cause death. In pregnant women, high levels of exposure to lead may cause miscarriage. Highlevel exposure in men can damage the organs responsible for sperm production [14].

Chromium, chromium (III) compounds and chromium metal are not considered a health hazard, while the toxicity and carcinogenic properties of chromium (VI) have been known since the late 19th century, while Cadmium exposure is a phenomenon of the early 20th century, and onwards. In Japan in 1910, the Mitsui mining and smelting Company discharging cadmium into the Jinzugawa River, as a byproduct of mining operations. Residents in the surrounding area subsequently consumed rice grown in cadmium-contaminated irrigation water, experienced softening of the bones and kidney failure [7].

\section{STUDY AREA}

Kano State was formally established on April 1, 1968. It is situated in a semi-arid region, located between latitudes $10.30^{\circ} \mathrm{N}$ to $13^{\circ} \mathrm{N}$ and longitude $7.40^{\circ} \mathrm{E}$ and $10.39^{\circ} \mathrm{E}$. Kano city is at 472.45 meters above sea level. The state is bordered by Jigawa State in the north-east, Katsina State in the north-west and Kaduna State is on the southern boundary. According to the 2006 census, the state has a population of 9.5 million with a projection of over 13 million in 2018. It has a total land area of 20,760 square kilometres with $1,754,200$ hectares for agricultural and 75,000 hectares forest vegetation and grazing land. The state is noted for its fairly stable climate with relatively minor changes in temperature and humidity [15]. Agriculture is the mainstay of the economy involving at least $75 \%$ of the rural population. Important crops produced in the State include maize, beans, rice, corn and varieties of vegetables.

\section{MATERIALS AND METHODS}

\subsection{Sample Collection and Preparation}

The samples were dehusked into grains washed with de-ionized water and dried to constant weight in a hot air oven at $105^{\circ} \mathrm{C}$ for $6 \mathrm{hrs}$, ground to powder and stored in clean air tied containers.

\subsubsection{Soil preparation and digestion}

Unwanted materials were removed from the soil. The samples was air dried in a clean room to avoid contamination and ground to pass through $600 \mu \mathrm{m}$ sieve and stored in polyethylene bags for analysis. $0.4 \mathrm{~g}$ of soil samples from each of the farm lands was weighed separately into a beaker. To each beaker, $3 \mathrm{ml}$ of concentrated $\mathrm{HCl}$ and $1 \mathrm{ml}$ of concentrated $\mathrm{HNO} 3$ was added and heated on a hot plate at $100^{\circ} \mathrm{C}$ for 10 minutes to destroy any oxidizable materials and carbonates. The solutions was topped with deionized water to the $50 \mathrm{ml}$ mark and filtered using a Whatman filter paper (No. 1). The filtrate was then analyzed for the presence of heavy metals.

\subsection{Analysis}

Five (5.0) $\mathrm{g}$ of the prepared samples of subsection 3.1 were air dried, ground in an agate mortar and was placed in quartz crucibles for dry ashing and mineralized thermally in a muffle furnace at $450^{\circ} \mathrm{C}$ for $12 \mathrm{hrs}$. The mineralized samples were then acid digested by dissolving in $20 \mathrm{ml}$ of $1: 1(\mathrm{v} / \mathrm{v})$ concentrated $\mathrm{HNO}_{3}$ and $\mathrm{HCl}$ acids in $100 \mathrm{ml}$ volumetric flask. The flask was then heated in an electro thermal heater with gentle swirling till digestion completed by the evolution of white fumes. The cooled digests were filtered through Whatman filter paper (No. 1) into a $50 \mathrm{ml}$ volumetric flask and were diluted 
to the mark with de-ionized water. The heavy metals content of the samples were determined using the atomic absorption spectrophotometer (AAS) and the concentration was calculated using the relation $y=m x+c$ from calibration of each metal standard [16].

\subsection{Determination of Pollution Load Index (PLI), Transfer Factor (TR), Daily Intake of Metals (DIM) and Health Risk Index (HRI)}

\subsubsection{Pollution Load Index (PLI)}

The following modified equation was used to determine the pollution load index (PLI) level in soils [17].

$$
\text { PLI }=\frac{C s}{C r}
$$

Where

$C_{\text {soil }}$ Concentration of metal in soil.

$C_{\text {reference }}$ Reference standard value of metal in soil.

\subsubsection{Transfer Factor (TF)}

Transfer factor (TF) from soil to grains was calculated as described by [17].

$$
\mathrm{TF}=\frac{C g}{C s}
$$

\section{Where}

$C_{g=}$ Concentration of metal in grains

$C_{s=}$ Concentration of metal in soil.

\subsubsection{Daily Intake of Metals (DIM)}

The Daily intake of metals (DIM) was determined as described by [18]

$\mathrm{DIM}=\frac{C g \times C f \times D f i}{B a b w}$

Where:

$C_{g}=$ concentration of heavy metals in grains $(\mathrm{mg} / \mathrm{kg})$

$C_{f}=0.085$

$D_{\text {fi }}$ (daily food intake) $=0.345 \mathrm{~kg}$ per day for adult

$B_{\text {abw }}$ (average body weight) $=55.90 \mathrm{~kg}$ for adult.

\subsubsection{Health Risk Index (HRI)}

Health risk index was calculated as described by [19].

$$
\mathrm{HRI}=\frac{D I M}{R F D}
$$

Where

$\mathrm{RFD}=$ reference oral dose

DIM= Daily intake of metals

\subsection{Statistical Analysis}

The data were expressed as mean \pm standard deviation, two-way ANOVA was conducted to examine the interaction between soil, beans and maize and Local Government Areas on the level of heavy metals ( $\mathrm{Hg}, \mathrm{Pb}, \mathrm{Cd}$ and $\mathrm{Cr}$ ). SPSS version 20.0 was used for statistical analyses and $P<0.05$ was set as level significant.

\section{RESULTS}

Fig. 1 shows the imperfect linear distribution of mean $\mathrm{Hg}$ concentration in samples of Bunkure (BKR), Danbatta (DBT), Gwarzo (GRZ), Ungogo (UGG) and Wudil (WDL) local government areas. The near zero linear coefficient ( $r$ ) correlation is suggesting the distribution of $\mathrm{Hg}$ across the local governments is not perfectly correlated. This is further supported by the square of the coefficient of multiple variations $\left(R^{2}\right)$, which gave a measure of the total variation in the dependent variable (soil), explained by variations in the explanatory variable (farm produce).

Fig. 2 displays weak linear correlations for the distribution of mean $\mathrm{Pb}$ levels in samples around Bunkure (BKR), Danbatta (DBT), Gwarzo (GRZ), Ungogo (UGG) and Wudil (WDL) local government of Kano state Nigeria, as indicated by the value of linear coefficient $(r)$. The measure of the total variation in the dependent variable $\left(R^{2}\right)$ further justifies that.

Strong non - linear correlation $(r=0.0015)$ for the distribution of mean $\mathrm{Cd}$ levels in samples around Bunkure (BKR),Danbatta (DBT), Gwarzo (GRZ), Ungogo (UGG) and Wudil (WDL) local government of Kano state Nigeria is shown on Fig. 3 with a reasonable measure of the total variation in the dependent variable $\left(R^{2}\right)$.

Fig. 4 shows an imperfect linear distribution of $\mathrm{Cr}$ in samples of Bunkure (BKR), Danbatta (DBT), Gwarzo (GRZ), Ungogo (UGG) and Wudil (WDL) 
local government of Kano state Nigeria. The near zero linear coefficient $(r)$ correlation is suggesting the distribution of the $\mathrm{Cr}$ across the local governments is not perfectly correlated. This is further substantiated by the value of the square of coefficient of multiple variations $\left(R^{2}\right)$, which gave a measure of the total variation in the dependent variable.

Table 1 shows the coefficient correlation matrix for Mercury $(\mathrm{Hg})$ distribution in soil, beans and maize of the five local government areas of the study. It showed a significant perfect correlation $(P<0.01)$ between; WDLS vs WDLM, DBTS vs GRZB, UGGS vs BKRB, WDLS vs BKRM, UGGM vs GRZM, UGGM vs WDLB and imperfect positive correlation between GRZS vs GRZB.

Table 2 shows the coefficient correlation of Lead $\mathrm{Pb}$ ) distribution in soil, and farm produces (beans and maize) in five local government areas of the study. The lead distributions show a significant negative correlation $(P<0.01)$ between the soil in DBT and the farm produce, maize in BKR and beans in WDL. In some instances, it shows a significant positive correlation $(P<0.01)$ between; DBTS vs UGGS and UGGB, BKRB vs WDLM, GRZB vs GRZM and WDLM and UGGM vs WDLS. Imperfect positive correlation was shown between the soil sample of each local government and respective farm produce.

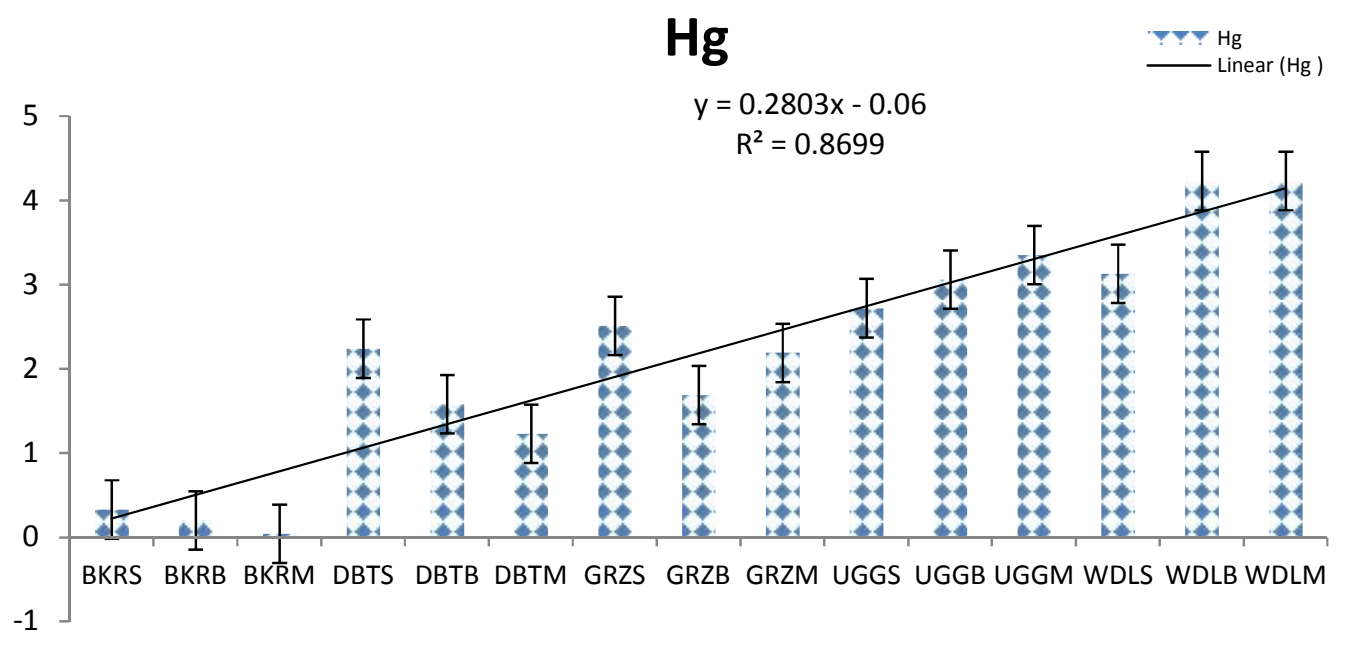

Fig. 1. Non-linear distribution of mean Hg levels in sample of Bunkure (BKR), Danbatta (DBT), Gwarzo (GRZ), Ungogo (UGG) and Wudil (WDL) local government of Kano state Nigeria

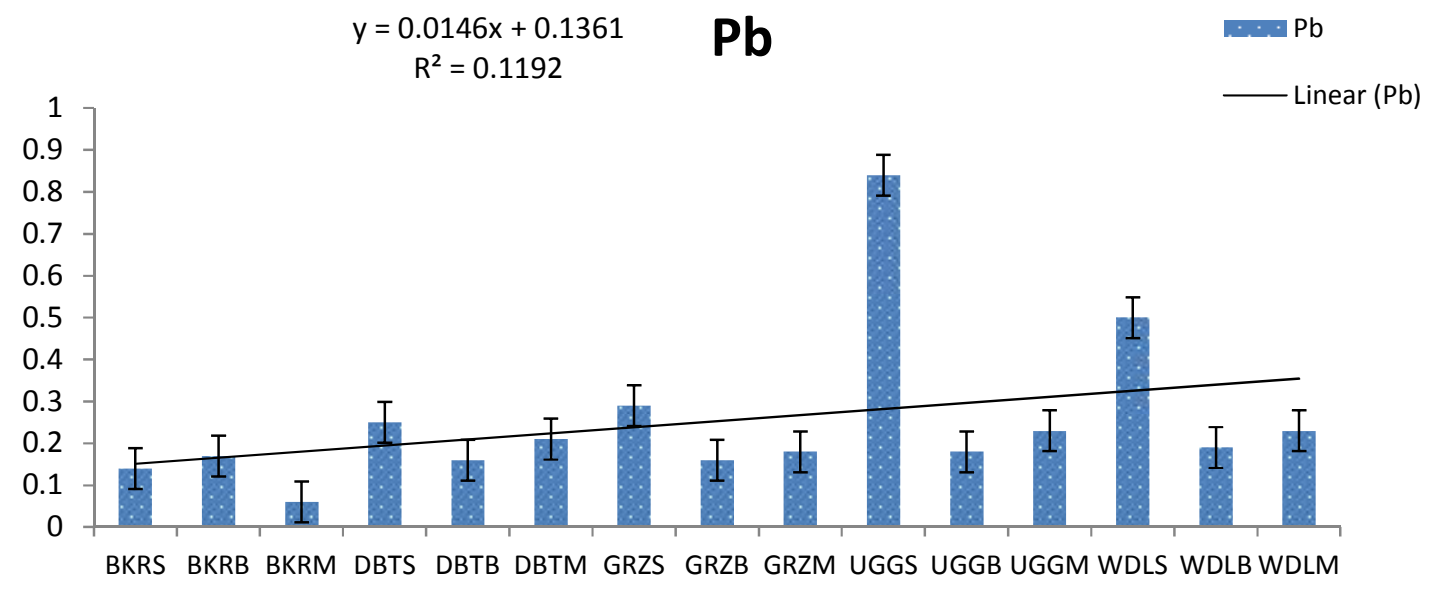

Fig. 2. Non-linear distribution of mean $\mathrm{Pb}$ concentration in sample of Bunkure (BKR), Danbatta (DBT), Gwarzo (GRZ), Ungogo (UGG) and Wudil (WDL) local government of Kano state Nigeria 


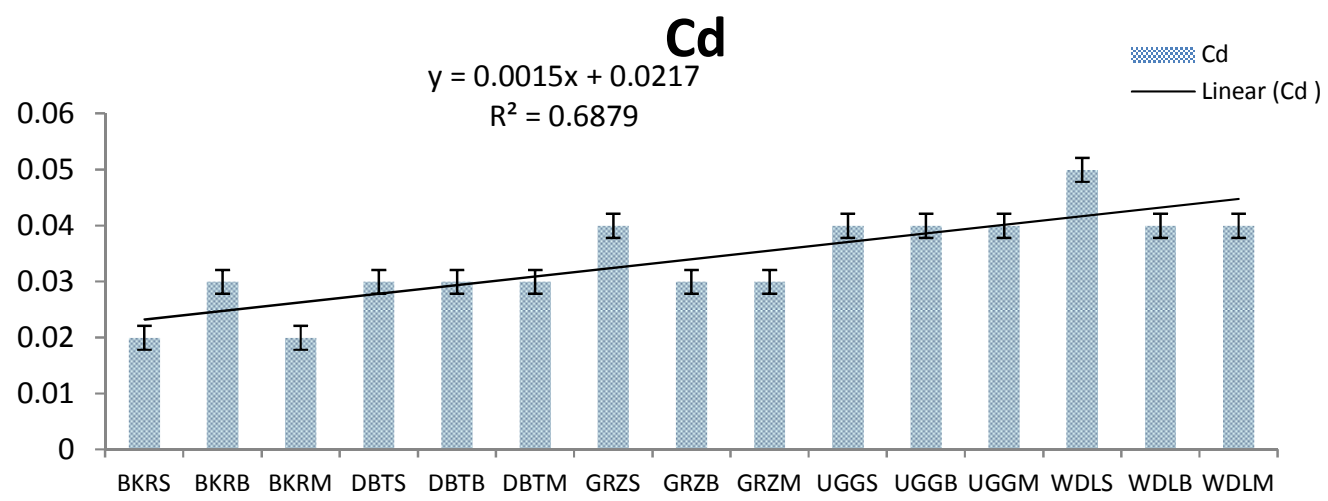

Fig. 3. Imperfect linear distribution of mean Cdvalue in sample of Bunkure (BKR), Danbatta (DBT), Gwarzo (GRZ), Ungogo (UGG) and Wudil (WDL) local government of Kano state Nigeria

Table 3 shows the coefficient correlation for the distribution of $\mathrm{Cd}$ in the Local Government Area under the study. It showed a significant positive correlation $(P<0.01)$ between; DBTB vs DBTS, BKRS vs DBTM, GRZS vs DBTS and DBTB, GRZM vs BKRB, UGGB vs BKRM, UGGM vs BKRB, WDLS vs DBTS, DBTB and GRZS, and WDLM, DBTM and BKRS. The distribution projects significant negative correlation between BKRM vs DBTM and BKRS, UGGB vs DBTM and BKRS, WDLM vs BKRM and UGGB. Cd distribution in soil of each local government under the study shows a negative correlation with that of maize except for UGG that shows a significant positive correlation $(P<0.01)$. The distribution showed a positive correlation with that of beans except in UGG and WDL.

The coefficient correlation of Chromium (Cr) distribution in the local government areas under study was shown on Table 4. It shows a significant correlation $(P<0.01)$ between; DBTS vs DBTB, DBTM, BKRB and GRZM, DBTB vs BKRB and GRZM, DBTM vs BKRB, GRZM, BKRS vs GRZB, GRZS vs WDLB, UGGS vs UGGB, UGGM vs WDLM. The lead distributions show a significant negative correlation $(P<0.01)$ in some instances Table 4.A positive correlation exists in each local government between soil and farm produce except in BKR and beans in GRZ and WDL that shows a negative correlation.

The pollution load index of toxic metals in five Local Government Areas, Kano State, Nigeria was shown in Table 5 . The result showed that the highest soil pollution load (PL) of Mercury was in Wudil (3.13 \pm 0.16$)$ followed by Ungogo soil with $\mathrm{Hg} \mathrm{PLI}$ of $2.72 \pm 0.48$, Gwarzo (2.51 \pm 0.46$)$ Danbatta (2.24 \pm 1.30$)$ and Bunkure with the lowest mercury PLI of $0.33 \pm 0.44$. Ungogo showed the highest soil PL of Lead $\left(5.6 \times 10^{-} 3\right.$ $\pm 0.04)$ while the lowest soil Lead PL was in Bunkure $\left(0.93 \times 10^{-3} \pm 0.08\right)$. Also, Wudil showed the highest $\mathrm{PL}$ of Cadmium $\left(1.6 \times 10^{-2} \pm 0.01\right)$ and $\mathrm{PL}$ of Chromium $\left(4.9 \times 10^{-3} \pm 0.01\right)$.

Table 6 shows the transfer factor of toxic metals from soil to grains in the five Local Government Areas under study. From this study, all the grains within the study zones exhibited a positive transfer factor, with the exception of Chromium in Bunkure, Danbatta and Gwarzo, where transfer factor was zero.

Table 7 show the daily intake of toxic metals in the five Local Government Areas under study. From the results, beans and maize from Wudil and Ungogo and maize from Gwarzo provided the highest daily intake of Mercury. This was followed by Gwarzo beans, beans and maize from Danbatta and Bunkure beans. The daily intake of Chromium from Bunkure beans and maize, Danbatta beans and maize and Gwarzo beans and maize was zero.

The health risk index of toxic metals across the five Local Government Areas, Kano State, Nigeria was presented in Table 8. From the results beans and maize from Wudil had the highest health risk index due to high Mercury content, followed by Ungogo, Gwarzo, Danbatta and Bunkure with the lowest health risk index of Mercury. All the remaining toxic metals showed a health risk index of less than one. 
Table 1. Coefficient correlation of mercury $(\mathrm{Hg})$ distribution in soil, beans and maize of five local government areas of Kano State Nigeria

\begin{tabular}{|c|c|c|c|c|c|c|c|c|c|c|c|c|c|c|c|}
\hline & $\begin{array}{l}\mathrm{Hg} \\
\text { DBTS }\end{array}$ & $\begin{array}{l}\mathrm{Hg} \\
\text { DBTB }\end{array}$ & $\begin{array}{l}\mathrm{Hg} \\
\text { DBTM }\end{array}$ & $\begin{array}{l}\mathrm{Hg} \\
\text { BKRS }\end{array}$ & $\begin{array}{l}\mathrm{Hg} \\
\text { BKRB }\end{array}$ & $\begin{array}{l}\mathrm{Hg} \\
\text { BKRM }\end{array}$ & $\begin{array}{l}\text { Hg } \\
\text { GRZS }\end{array}$ & $\begin{array}{l}\mathrm{Hg} \\
\text { GRZB }\end{array}$ & $\begin{array}{l}\mathrm{Hg} \\
\text { GRZM }\end{array}$ & $\begin{array}{l}\text { Hg } \\
\text { UGGS }\end{array}$ & $\begin{array}{l}\text { Hg } \\
\text { UGGB }\end{array}$ & $\begin{array}{l}\text { Hg } \\
\text { UGGM }\end{array}$ & $\begin{array}{l}\mathrm{Hg} \\
\text { WDLS }\end{array}$ & $\begin{array}{l}\mathrm{Hg} \\
\text { WDLB }\end{array}$ & $\begin{array}{l}\mathrm{Hg} \\
\text { WDLM }\end{array}$ \\
\hline HgDBTS & 1.000 & & & & & & & & & & & & & & \\
\hline HgDBTB & .000 & 1.000 & & & & & & & & & & & & & \\
\hline HgDBTM & .000 & $-1.000^{\pi \pi}$ & 1.000 & & & & & & & & & & & & \\
\hline HgBKRS & .816 & .500 & -.500 & 1.000 & & & & & & & & & & & \\
\hline HgBKRB & $-1.000^{\pi x}$ & .000 & .000 & -.816 & 1.000 & & & & & & & & & & \\
\hline HgBKRM & .333 & -.816 & .816 & .000 & -.333 & 1.000 & & & & & & & & & \\
\hline HgGRZS & .816 & -.500 & .500 & .500 & -.816 & .816 & 1.000 & & & & & & & & \\
\hline HgGRZB & $1.000^{\pi \pi}$ & .000 & .000 & .816 & $-1.000^{\pi x}$ & .333 & .816 & 1.000 & & & & & & & \\
\hline HgGRZM & .333 & .816 & -.816 & .816 & -.333 & -.333 & .000 & .333 & 1.000 & & & & & & \\
\hline HgUGGS & $-1.000^{\pi \times}$ & .000 & .000 & -.816 & $1.000^{\pi \pi}$ & -.333 & -.816 & $-1.000^{\pi \times}$ & -.333 & 1.000 & & & & & \\
\hline HgUGGB & .000 & $1.000^{* *}$ & $-1.000^{\star *}$ & .500 & .000 & -.816 & -.500 & .000 & .816 & .000 & 1.000 & & & & \\
\hline HgUGGM & .333 & .816 & -.816 & .816 & -.333 & -.333 & .000 & .333 & $1.000^{* *}$ & -.333 & .816 & 1.000 & & & \\
\hline HgWDLS & .333 & -.816 & .816 & .000 & -.333 & $1.000^{\pi \pi}$ & .816 & .333 & -.333 & -.333 & -.816 & -.333 & 1.000 & & \\
\hline HgWDLB & .333 & .816 & -.816 & .816 & -.333 & -.333 & .000 & .333 & $1.000^{* \pi}$ & -.333 & .816 & $1.000^{* *}$ & -.333 & 1.000 & \\
\hline HgWDLM & .333 & -.816 & .816 & .000 & -.333 & $1.000^{* \pi}$ & .816 & .333 & -.333 & -.333 & -.816 & -.333 & $1.000^{* x}$ & -.333 & 1.000 \\
\hline
\end{tabular}

Table 2. Coefficient correlation of lead $(\mathrm{Pb})$ distribution in soil, beans and maize of five local government areas of Kano State Nigeria

\begin{tabular}{|c|c|c|c|c|c|c|c|c|c|c|c|c|c|c|c|}
\hline & $\begin{array}{l}\mathrm{Pb} \\
\mathrm{DBTS}\end{array}$ & $\begin{array}{l}\mathrm{Pb} \\
\mathrm{DBTB}\end{array}$ & $\begin{array}{l}\text { Pb } \\
\text { DBTM }\end{array}$ & $\begin{array}{l}\mathrm{Pb} \\
\text { BKRS }\end{array}$ & $\begin{array}{l}\text { Pb } \\
\text { BKRB }\end{array}$ & $\begin{array}{l}\text { Pb } \\
\text { BKRM }\end{array}$ & $\begin{array}{l}\mathrm{Pb} \\
\text { GRZS }\end{array}$ & $\begin{array}{l}\text { Pb } \\
\text { GRZB }\end{array}$ & $\begin{array}{l}\text { Pb } \\
\text { GRZM }\end{array}$ & $\begin{array}{l}\text { Pb } \\
\text { UGGS }\end{array}$ & $\begin{array}{l}\text { Pb } \\
\text { UGGB }\end{array}$ & $\begin{array}{l}\text { Pb } \\
\text { UGGM }\end{array}$ & $\begin{array}{l}\text { Pb } \\
\text { WDLS }\end{array}$ & $\begin{array}{l}\text { Pb } \\
\text { WDLB }\end{array}$ & $\begin{array}{l}\text { Pb } \\
\text { WDLM }\end{array}$ \\
\hline PbDBTS & 1.000 & & & & & & & & & & & & & & \\
\hline PbDBTB & $-1.000^{\pi x}$ & 1.000 & & & & & & & & & & & & & \\
\hline PbDBTM & $-1.000^{* \pi}$ & $1.000^{\star x}$ & 1.000 & & & & & & & & & & & & \\
\hline PbBKRS & $-1.000^{\star *}$ & $1.000^{* \pi}$ & $1.000^{\star x}$ & 1.000 & & & & & & & & & & & \\
\hline PbBKRB & -.333 & .333 & .333 & .333 & 1.000 & & & & & & & & & & \\
\hline PbBKRM & $1.000^{\star *}$ & $-1.000^{\star *}$ & $-1.000^{* *}$ & $-1.000^{\star *}$ & -.333 & 1.000 & & & & & & & & & \\
\hline PbGRZS & .333 & -.333 & -.333 & -.333 & .333 & .333 & 1.000 & & & & & & & & \\
\hline PbGRZB & -.333 & .333 & .333 & .333 & $1.000^{\star *}$ & -.333 & .333 & 1.000 & & & & & & & \\
\hline PbGRZM & -.333 & .333 & .333 & .333 & $1.000^{\star *}$ & -.333 & .333 & $1.000^{* *}$ & 1.000 & & & & & & \\
\hline PbUGGS & $1.000^{\star *}$ & $-1.000^{* *}$ & $-1.000^{* *}$ & $-1.000^{* *}$ & -.333 & $1.000^{* *}$ & .333 & -.333 & -.333 & 1.000 & & & & & \\
\hline
\end{tabular}




\begin{tabular}{|c|c|c|c|c|c|c|c|c|c|c|c|c|c|c|c|}
\hline & $\begin{array}{l}\mathrm{Pb} \\
\mathrm{DBTS}\end{array}$ & $\begin{array}{l}\mathrm{Pb} \\
\mathrm{DBTB}\end{array}$ & $\begin{array}{l}\mathrm{Pb} \\
\mathrm{DBTM}\end{array}$ & $\begin{array}{l}\mathrm{Pb} \\
\text { BKRS }\end{array}$ & $\begin{array}{l}\mathrm{Pb} \\
\text { BKRB }\end{array}$ & $\begin{array}{l}\mathrm{Pb} \\
\text { BKRM }\end{array}$ & $\begin{array}{l}\mathrm{Pb} \\
\text { GRZS }\end{array}$ & $\begin{array}{l}\mathrm{Pb} \\
\text { GRZB }\end{array}$ & $\begin{array}{l}\mathrm{Pb} \\
\text { GRZM }\end{array}$ & $\begin{array}{l}\text { Pb } \\
\text { UGGS }\end{array}$ & $\begin{array}{l}\mathrm{Pb} \\
\text { UGGB }\end{array}$ & $\begin{array}{l}\text { Pb } \\
\text { UGGM }\end{array}$ & $\begin{array}{l}\mathrm{Pb} \\
\text { WDLS }\end{array}$ & $\begin{array}{l}\mathrm{Pb} \\
\text { WDLB }\end{array}$ & $\begin{array}{l}\mathrm{Pb} \\
\text { WDLM }\end{array}$ \\
\hline PbUGGB & $1.000^{*}$ & $-1.000^{*}$ & -1.000 & -1.000 & -.333 & $1.000^{* *}$ & .333 & -.333 & -.333 & $1.000^{*}$ & 1.000 & & & & \\
\hline PbUGGM & .333 & -.333 & -.333 & -.333 & .333 & .333 & $1.000^{* \pi}$ & .333 & .333 & .333 & .333 & 1.000 & & & \\
\hline PbWDLS & .333 & -.333 & -.333 & -.333 & .333 & .333 & $1.000^{* \pi}$ & .333 & .333 & .333 & .333 & $1.000^{* *}$ & 1.000 & & \\
\hline PbWDLB & -.333 & .333 & .333 & .333 & -.333 & -.333 & $-1.000^{* \pi}$ & -.333 & -.333 & -.333 & -.333 & $-1.000^{* \pi}$ & $-1.000^{\star *}$ & 1.000 & \\
\hline PbWDLM & -.333 & .333 & .333 & .333 & $1.000^{\star \pi}$ & -.333 & .333 & $1.000^{\pi \pi}$ & $1.000^{\pi \pi}$ & -.333 & -.333 & .333 & .333 & -.333 & 1.000 \\
\hline
\end{tabular}

Table 3. Coefficient correlation of cadmium (Cd) distribution in soil, beans and maize of five local government areas of Kano state Nigeria

\begin{tabular}{|c|c|c|c|c|c|c|c|c|c|c|c|c|c|c|c|}
\hline & $\begin{array}{l}\text { Cd } \\
\text { DBTS }\end{array}$ & $\begin{array}{l}\text { Cd } \\
\text { DBTB }\end{array}$ & $\begin{array}{l}\text { Cd } \\
\text { DBTM }\end{array}$ & $\begin{array}{l}\text { Cd } \\
\text { BKRS }\end{array}$ & $\begin{array}{l}\text { Cd } \\
\text { BKRB }\end{array}$ & $\begin{array}{l}\text { Cd } \\
\text { BKRM }\end{array}$ & $\begin{array}{l}\text { Cd } \\
\text { GRZS }\end{array}$ & $\begin{array}{l}\text { Cd } \\
\text { GRZB }\end{array}$ & $\begin{array}{l}\text { Cd } \\
\text { GRZM }\end{array}$ & $\begin{array}{l}\text { Cd } \\
\text { UGGS }\end{array}$ & $\begin{array}{l}\text { Cd } \\
\text { UGGB }\end{array}$ & $\begin{array}{l}\text { Cd } \\
\text { UGGM }\end{array}$ & $\begin{array}{l}\text { Cd } \\
\text { WDLS }\end{array}$ & $\begin{array}{l}\text { Cd } \\
\text { WDLB }\end{array}$ & $\begin{array}{l}\text { Cd } \\
\text { WDLM }\end{array}$ \\
\hline CdDBTS & 1.000 & & & & & & & & & & & & & & \\
\hline CdDBTB & $1.000^{\star x}$ & 1.000 & & & & & & & & & & & & & \\
\hline CdDBTM & -.333 & -.333 & 1.000 & & & & & & & & & & & & \\
\hline CdBKRS & -.333 & -.333 & $1.000^{* \pi}$ & 1.000 & & & & & & & & & & & \\
\hline CdBKRB & .333 & .333 & .333 & .333 & 1.000 & & & & & & & & & & \\
\hline CdBKRM & .333 & .333 & $-1.000^{\pi x}$ & $-1.000^{\pi \pi}$ & -.333 & 1.000 & & & & & & & & & \\
\hline CdGRZS & $1.000^{\star \pi}$ & $1.000^{* *}$ & -.333 & -.333 & .333 & .333 & 1.000 & & & & & & & & \\
\hline CdGRZB & .816 & .816 & .000 & .000 & .816 & .000 & .816 & 1.000 & & & & & & & \\
\hline CdGRZM & .333 & .333 & .333 & .333 & $1.000^{\star \pi}$ & -.333 & .333 & .816 & 1.000 & & & & & & \\
\hline CdUGGS & .333 & .333 & .333 & .333 & $1.000^{* *}$ & -.333 & .333 & .816 & $1.000^{\star \pi}$ & 1.000 & & & & & \\
\hline CdUGGB & .333 & .333 & $-1.000^{* \pi}$ & $-1.000^{\star *}$ & -.333 & $1.000^{* *}$ & .333 & .000 & -.333 & -.333 & 1.000 & & & & \\
\hline CdUGGM & .333 & .333 & .333 & .333 & $1.000^{\pi *}$ & -.333 & .333 & .816 & $1.000^{\star \pi}$ & $1.000^{* \pi}$ & -.333 & 1.000 & & & \\
\hline CdWDLS & $1.000^{* \pi}$ & $1.000^{\star x}$ & -.333 & -.333 & .333 & .333 & $1.000^{* *}$ & .816 & .333 & .333 & .333 & .333 & 1.000 & & \\
\hline CdWDLB & .000 & .000 & -.816 & -.816 & -.816 & .816 & .000 & -.500 & -.816 & -.816 & .816 & -.816 & .000 & 1.000 & \\
\hline CdWDLM & -.333 & -.333 & $1.000^{* \pi}$ & $1.000^{\star *}$ & .333 & $-1.000^{\star *}$ & -.333 & .000 & .333 & .333 & $-1.000^{\star *}$ & .333 & -.333 & -.816 & 1.000 \\
\hline
\end{tabular}


Table 4. Coefficient correlation of chromium ( $\mathrm{Cr}$ ) distribution in soil, beans and maize of five local government areas of Kano State Nigeria

\begin{tabular}{|c|c|c|c|c|c|c|c|c|c|c|c|c|c|c|c|}
\hline & $\begin{array}{l}\text { Cr } \\
\text { DBTS }\end{array}$ & $\begin{array}{l}\text { Cr } \\
\text { DBTB }\end{array}$ & $\begin{array}{l}\text { Cr } \\
\text { DBTM }\end{array}$ & $\begin{array}{l}\text { Cr } \\
\text { BKRS }\end{array}$ & $\begin{array}{l}\text { Cr } \\
\text { BKRB }\end{array}$ & $\begin{array}{l}\text { Cr } \\
\text { BKRM }\end{array}$ & $\begin{array}{l}\mathbf{C r} \\
\text { GRZS }\end{array}$ & $\begin{array}{l}\text { Cr } \\
\text { GRZB }\end{array}$ & $\begin{array}{l}\text { Cr } \\
\text { GRZM }\end{array}$ & $\begin{array}{l}\text { Cr } \\
\text { UGGS }\end{array}$ & $\begin{array}{l}\text { Cr } \\
\text { UGGB }\end{array}$ & $\begin{array}{l}\text { Cr } \\
\text { UGGM }\end{array}$ & $\begin{array}{l}\text { Cr } \\
\text { WDLS }\end{array}$ & $\begin{array}{l}\text { Cr } \\
\text { WDLB }\end{array}$ & $\begin{array}{l}\text { Cr } \\
\text { WDLM }\end{array}$ \\
\hline CrDBTS & 1.000 & & & & & & & & & & & & & & \\
\hline CrDBTB & $1.000^{* \pi}$ & 1.000 & & & & & & & & & & & & & \\
\hline CrDBTM & $1.000^{\pi \pi}$ & $1.000^{\pi \pi}$ & 1.000 & & & & & & & & & & & & \\
\hline CrBKRS & -.500 & -.500 & -.500 & 1.000 & & & & & & & & & & & \\
\hline CrBKRB & $1.000^{\pi \pi}$ & $1.000^{\star \pi}$ & $1.000^{\pi \pi}$ & -.500 & 1.000 & & & & & & & & & & \\
\hline CrBKRM & -.500 & -.500 & -.500 & -.500 & -.500 & 1.000 & & & & & & & & & \\
\hline CrGRZS & -.816 & -.816 & -.816 & .000 & -.816 & .816 & 1.000 & & & & & & & & \\
\hline CrGRZB & -.500 & $-.500_{* \star}$ & $-.500_{x x}$ & $1.000^{\star \pi}$ & -.500 & -.500 & .000 & 1.000 & & & & & & & \\
\hline CrGRZM & $1.000^{\star *}$ & $1.000^{* *}$ & $1.000^{* *}$ & -.500 & $1.000^{* *}$ & -.500 & -.816 & -.500 & 1.000 & & & & & & \\
\hline CrUGGS & .816 & .816 & .816 & -.816 & .816 & .000 & -.333 & -.816 & .816 & 1.000 & & & & & \\
\hline CrUGGB & .816 & .816 & .816 & -.816 & .816 & .000 & -.333 & -.816 & .816 & $1.000^{* *}$ & 1.000 & & & & \\
\hline CrUGGM & .816 & .816 & .816 & .000 & .816 & -.816 & $-1.000^{\star x x}$ & .000 & .816 & .333 & .333 & 1.000 & & & \\
\hline CrWDLS & -.816 & -.816 & -.816 & .816 & -.816 & .000 & .333 & .816 & -.816 & $-1.000^{\pi \pi}$ & $-1.000^{\pi \pi}$ & -.333 & 1.000 & & \\
\hline CrWDLB & -.816 & -.816 & -.816 & .000 & -.816 & .816 & $1.000^{* \pi}$ & .000 & -.816 & -.333 & -.333 & $-1.000^{* x}$ & .333 & 1.000 & \\
\hline CrWDLM & .816 & .816 & .816 & .000 & .816 & -.816 & $-1.000^{* \pi}$ & .000 & .816 & .333 & .333 & $1.000^{* \pi}$ & -.333 & $-1.000^{\star x}$ & 1.000 \\
\hline
\end{tabular}


Table 5. Toxic metals pollution load index in the soil of five local government areas, Kano State, Nigeria

\begin{tabular}{lllll}
\hline Study area & $\mathbf{H g}$ & $\mathbf{P b}$ & $\mathbf{C d}$ & $\mathbf{C r}$ \\
\hline Bunkure & $0.33 \pm 0.44$ & $0.93 \times 10^{-3} \pm 0.08$ & $0.67 \times 10^{-2} \pm 0.00$ & $0.1 \times 10^{-3} \pm 0.02$ \\
Danbatta & $2.24 \pm 1.30$ & $1.66 \times 10^{-3} \pm 0.13$ & $1.0 \times 10^{-2} \pm 0.00$ & $0.2 \times 10^{-3} \pm 0.02$ \\
Gwarzo & $2.51 \pm 0.46$ & $1.9 \times 10^{-3} \pm 0.05$ & $1.3 \times 10^{-2} \pm 0.00$ & $1.5 \times 10^{-3} \pm 0.03$ \\
Ungogo & $2.72 \pm 0.48$ & $5.6 \times 10^{-3} \pm 0.04$ & $1.3 \times 10^{-2} \pm 0.00$ & $4.4 \times 10^{-3} \pm 0.04$ \\
Wudil & $3.13 \pm 0.16$ & $3.3 \times 10^{-3} \pm 0.01$ & $1.6 \times 10^{-2} \pm 0.01$ & $4.9 \times 10^{-3} \pm 0.01$ \\
\hline
\end{tabular}

Table 6. The transfer factor of toxic metals from soil to grains from five local government areas, Kano State, Nigeria

\begin{tabular}{lllllllll}
\hline \multirow{2}{*}{ Study area } & \multicolumn{2}{c}{ Hg } & \multicolumn{2}{c}{ Pb } & \multicolumn{2}{c}{ Cd } & \multicolumn{2}{c}{ Cr } \\
\cline { 2 - 9 } & Beans & Maize & Beans & Maize & Beans & Maize & Beans & Maize \\
\hline Bunkure & 0.60 & 0.12 & 1.21 & 0.42 & 1.5 & 1 & 0 & 0 \\
Danbatta & 0.70 & 0.54 & 0.64 & 0.84 & 1 & 1 & 0 & 0 \\
Gwarzo & 0.67 & 0.87 & 0.55 & 0.62 & 0.75 & 0.75 & 0 & 0 \\
Ungogo & 1.12 & 1.23 & 0.21 & 0.27 & 1 & 1 & 0.06 & 0.22 \\
Wudil & 1.35 & 1.35 & 0.38 & 0.46 & 0.80 & 0.80 & 0.06 & 0.12 \\
\hline
\end{tabular}

Table 7. Daily intake of toxic metals in beans and maize across five local government areas under study

\begin{tabular}{lllllllll}
\hline \multirow{2}{*}{$\begin{array}{l}\text { Study } \\
\text { area }\end{array}$} & \multicolumn{2}{c}{ Hg } & \multicolumn{2}{c}{ Pb } & \multicolumn{2}{c}{ Cd } & \multicolumn{2}{c}{ Cr } \\
\cline { 2 - 8 } & Beans & Maize & Beans & Maize & Beans & Maize & Beans & Maize \\
\hline Bunkure & $1.0 \times 10^{-4}$ & $2.0 \times 10^{-5}$ & $8.9 \times 10^{-5}$ & $3.1 \times 10^{-5}$ & $1.5 \times 10^{-5}$ & $1.0 \times 10^{-5}$ & 0 & 0 \\
Danbatta & $8.2 \times 10^{-4}$ & $6.4 \times 10^{-4}$ & $8.3 \times 10^{-5}$ & $1.0 \times 10^{-5}$ & $1.5 \times 10^{-5}$ & $1.5 \times 10^{-5}$ & 0 & 0 \\
Gwarzo & $8.8 \times 10^{-4}$ & $1.1 \times 10^{-3}$ & $8.3 \times 10^{-5}$ & $9.4 \times 10^{-5}$ & $1.5 \times 10^{-5}$ & $1.5 \times 10^{-5}$ & 0 & 0 \\
Ungogo & $1.6 \times 10^{-3}$ & $1.7 \times 10^{-3}$ & $9.4 \times 10^{-5}$ & $1.2 \times 10^{-4}$ & $2.0 \times 10^{-5}$ & $2.0 \times 10^{-5}$ & $1.5 \times 10^{-5}$ & $5.2 \times 10^{-5}$ \\
Wudil & $2.2 \times 10^{-3}$ & $2.2 \times 10^{-3}$ & $9.9 \times 10^{-5}$ & $1.2 \times 10^{-4}$ & $2.0 \times 10^{-5}$ & $2.0 \times 10^{-5}$ & $1.0 \times 10^{-5}$ & $3.1 \times 10^{-5}$ \\
\hline
\end{tabular}

Table 8. Health risk index in beans and maize across five zones in Kano State, Nigeria

\begin{tabular}{lllllllll}
\hline Study area & \multicolumn{2}{c}{ Hg } & \multicolumn{2}{c}{ Pb } & \multicolumn{2}{c}{ Cd } & \multicolumn{2}{c}{ Cr } \\
\cline { 2 - 9 } & Beans & Maize & Beans & Maize & Beans & Maize & Beans & Maize \\
\hline Bunkure & 0.33 & 0.10 & 0.025 & 0.008 & 0.015 & 0.01 & 0 & 0 \\
Danbatta & 2.7 & 2.1 & 0.023 & 0.003 & 0.015 & 0.015 & 0 & 0 \\
Gwarzo & 2.9 & 3.6 & 0.023 & 0.026 & 0.015 & 0.015 & 0 & 0 \\
Ungogo & 5.3 & 5.6 & 0.026 & 0.035 & 0.02 & 0.02 & 0 & 0 \\
Wudil & 7.3 & 7.3 & 0.028 & 0.035 & 0.02 & 0.02 & 0 & 0 \\
\hline
\end{tabular}

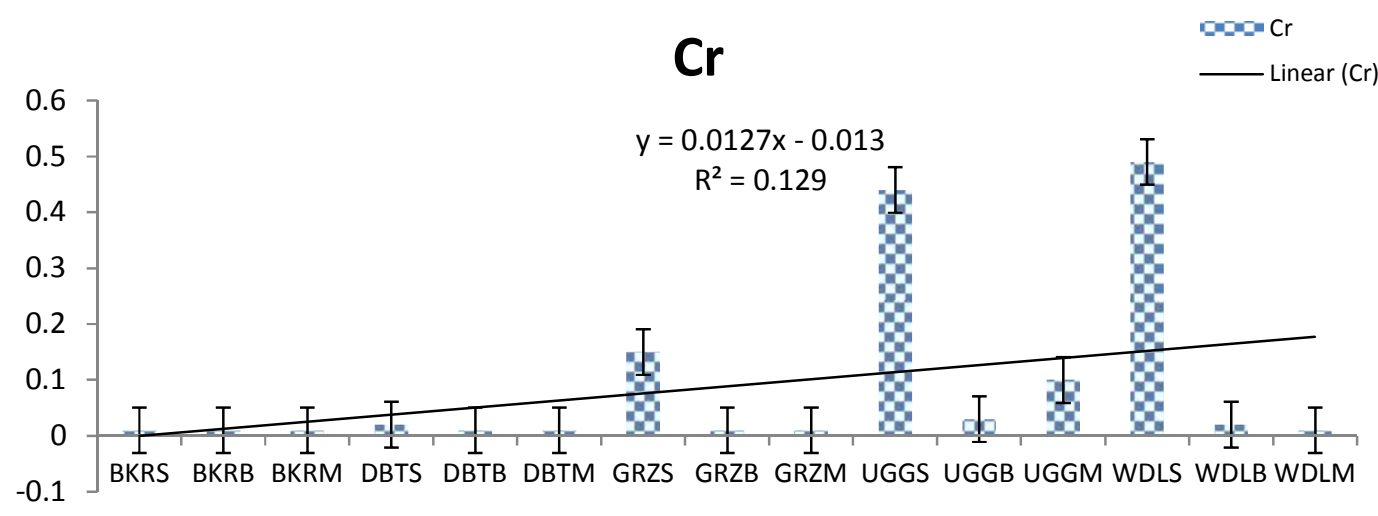

Fig. 4. Imperfect linear distribution of mean Crvalue in sample of Bunkure (BKR), Danbatta (DBT), Gwarzo (GRZ), Ungogo (UGG) and Wudil (WDL) local government of Kano state Nigeria 


\section{DISCUSSION}

The current study evaluated the levels of toxic metals (mercury, lead, cadmium and chromium) in soil and farm produce (maize and beans) of five local governments of Kano state. Mean $\mathrm{Pb}$, $\mathrm{Cd}$ and $\mathrm{Cr}$ concentration of the soil samples were within the respective limits of $150 \mathrm{mg} / \mathrm{Kg}, 3$ $\mathrm{mg} / \mathrm{kg}$ and $100 \mathrm{mg} / \mathrm{Kg}$ set by International Standard tolerable limits [20]. However, with the exception of BKRS, all soil samples have mean mercury $(\mathrm{Hg})$ concentration above $1 \mathrm{mg} / \mathrm{Kg}$, the limits set by international standard tolerable limits [20]. Mean $\mathrm{Pb}, \mathrm{Cd}$ and $\mathrm{Cr}$ levels in beans and maize of the study area were all within the respective limits of $0.3 \mathrm{mg} / \mathrm{kg}, 0.2 \mathrm{mg} / \mathrm{kg}$ and 0.2 $\mathrm{mg} / \mathrm{kg}$ set by International Standard tolerable limits [20]. While mean $\mathrm{Hg}$ concentrations in beans and maize are above $0.05 \mathrm{mg} / \mathrm{kg}$ tolerable limit set by international standard tolerable limits [20]. Although, the mean levels of $\mathrm{Pb}, \mathrm{Cr}$ and $\mathrm{Cd}$ were within the tolerable limit, however, attention should be focused on low-level chronic exposure to these toxic metals, mercury inclusive.

The study shows that the spatial soil distribution of the toxic metals in each of the study areas was significantly $(P<0.01)$ correlated with levels in the farm produce. The significant $(P<0.01)$ negative correlation may indicate uptake/removal of the toxic metals from soil into the crops, while the instances of positive significant $(P<0.01)$ correlation may indicate additional point sources of these metals, possible from the application of agrochemicals (fertilizers, pesticides and herbicides) and/or from non-point sources such as runoff from environmental waste deposits of organic manure of animal origin, this is in line with the findings of Alhassan et al. [4] who established a higher reference value of some of these toxic metals in road-side dust.

The established levels of these toxic metals in the farm produce relative to soil concentration could be alarming and may indicate their buildup to the food chain. It may, therefore, serve as a means of exposing the human population to these toxic metals. This may be convinced by considering the outstanding characteristics of elements "non-destroyable and bioaccumulating". The findings of the study established alarming concentration of $\mathrm{Hg}$ in most of the samples analyzed, despite the non or less toxic effect due to exposure of low levels of metallic mercury speculated by some researchers [13], biotransformation of the inorganic $\mathrm{Hg}$ to organic $\mathrm{Hg}$ such as methyl mercury may occur, that potentiate the toxic effects of the mercury which include lung damage, nausea, vomiting, diarrhea, increase in blood pressure or heart rate, skin rashes, eye irritation, permanently damage to brain, kidneys, and developing fetuses [12,13]. Alhassan et al. [4] pointed out that human exposure to lead may result in many biological effects depending on the level and duration of exposure. Lead resembles calcium as divalent ion, it is therefore handled by the body as if it were $\mathrm{Ca}^{2+}$, hence replacing the calcium in many biological systems and protein matrix with concomitant loss in biological activity. In addition, other biochemical toxicity of lead could be associated to its affinity to cell membrane and mitochondria, where it interfere with oxidative phosphorylation, it also interferes with $\mathrm{Na}^{+}, \mathrm{K}^{+}$and $\mathrm{Ca}^{2+}$ ATP-ase pumps [21]. Chronic lead exposure to blood level $>1.4$ $\mu \mathrm{g} / \mathrm{l}$ in children is believed to cause mental retardation, selective deficits in language, cognitive function, balance, behavioral and school performance. Across all age chronic exposure to lead is associated with kidney damage and interstitial nephritis, affect sperm and ova, anaemia, CNS defects, peripheral neuropathies, and reduced birth weight. Susceptibility to lead toxicity is governed by genetic factors, as established in Caucasians population with $15 \%$ variant of gene code for aminolevulinic acid dehydrogenase, hence become more susceptible to lead exposure [22].

Cadmium is a very toxic metal, found in all soils, including coal and mineral fertilizers. Cadmium has many uses, including batteries, pigments, metal coatings, and plastics. It is used extensively in electroplating [23]. Cadmium and cadmium compounds are known human carcinogens. Smokers get exposed to significantly higher cadmium levels than nonsmokers. Severe damage to the lungs may occur through breathing high levels of cadmium common to cigarette smokers. High levels ingestion induces severe stomach irritation that induces vomiting and diarrhea, while Long-term exposure to lower levels leads to a buildup in the kidneys and possible kidney disease, lung damage, and fragile bones [24].

Chromium is found in rocks, animals, plants, and soil, its compounds bind to soil and are not likely to migrate to groundwater but, they are very persistent in sediments in the water. Chromium is used in metal alloys such as stainless steel; protective coatings on metal (electroplating); 
magnetic tapes; and pigments for paints, cement, paper, rubber, composition floor covering and other materials. Its soluble forms are used in wood preservatives [25]. Chromium (VI) compounds are toxins and known human carcinogens, whereas Chromium (III) is an essential nutrient. Breathing high levels can cause irritation to the lining of the nose; nose ulcers; runny nose; and breathing problems, such as asthma, cough, shortness of breath, or wheezing [26].

The level of Cadmium and Chromium in the soil, beans and maize samples from all the local government are not considered a health hazard. However, chronic exposure to such low levels may lead to the toxicity and carcinogenic properties of chromium, softening of bones and kidney failure. It is worth noting that most of the above mentioned sign and symptoms of heavy metals toxicity could be very common clinical cases in most hospitals nowadays and may not be unconnected to the buildup of these toxic metals in foods and ultimately in human tissues.

Based on the findings of this study, mercury was found to possess a health risk index in four of the five Local Government Areas studied. The calculated health risk index of mercury in the studied areas was greater than one, and which shows an obvious risk of exposure by the population in the zones [27]. According to the world health organization, the majority of mercury in the environment results from the coal-fired power station, residential heating systems and waste incinerators. Mercury is also released into the environment in the process of mining gold and other metals [28]. WHO [28], also established that consumption of contaminated fish, shellfish and marine mammals is the main source of methyl mercury exposure, especially for people who rely on predatory fish as their main source of protein. A recently conducted study by Zhang et al. [27] found an elevated concentration of methyl mercury in rice (9.3 $\mathrm{ug} / \mathrm{kg}$ ) throughout the Guizhou province of China. According to the Al-saleh and Shinwari, [29], mercury continues to be found in rice even in regions where mercury-based pesticides are no longer in use. A study conducted in Saudi Arabia found that the concentration in rice was (3.18 $\mathrm{ug} / \mathrm{kg}$ ). In addition to past or ongoing fungicide use, mining and other industrial activities introduce another route of mercury exposure into the food chain through grain consumption in some regions of the world.

\section{CONCLUSION}

Heavy metals contamination constitutes a major factor in environmental pollution. However, from this study, the results Show that all metals are below the limit tolerated by the legislation. However, it is imperative to note that chronic exposure to these even at low concentrations should be avoided.

\section{COMPETING INTERESTS}

Authors have declared that no competing interests exist.

\section{REFERENCES}

1. Alloway BJ. Heavy metals in soils $2^{\text {nd }}$ edition, Blackie academic and professional, Glasgow. 1995;500.

2. Holding BV. Heavy metals; 2004. Available:http:www.Lenntech.Com/heavy metals.htm

3. World Health Organization (WHO). Joint FAO/WHO Food Standards Programme. Codex Committee on Food Additives and Contaminants. Thirty-Second Session. Draft maximum levels of lead. Prepared by Denmark. 2014;389.

4. Alhassan AJ, Sule MS, Atiku MK, Wudil AM, Dangambo MA, Mashi JA, Ibrahim NA. Study of correlation between heavy metal concentration, street dust and level of traffic in major roads of Kano Metropolis, Nigeria. Nigerian Journal of Basic and Applied Science. 2012;20(2):161-168.

5. Madyiwa S. Modeling lead and cadmium uptake by star grass under irrigation with treated waste water. Published Philosophiae. Doctor Thesis, University of Pretoria, South Africa. 2006;44-51.

6. Rajeswari TR, Sailaja N. Impact of heavy metals on environmental pollution. Journal of Chemical and Pharmaceutical Sciences. 2014;3:175-181.

7. Gray CW, Mclaren RC, Roberts AHC. Atmospheric accessions of heavy metals to some New Zealand pastoral soils. The Science of the Total Environment. 2003;305:105-115.

8. Garrett NE, Garrett RJB, Archdeacon JW. Placental transmission of mercury to foetal rat. Toxicological Application Pharmacological. 1992;22:649-654.

9. Carpenter DO. Effects of metals on the nervous system of humans and metals. International Journal of Occupational 
Medicine and Environmental Health. 2001;14(3):209-218.

10. Srivastava S, Goyal P. Novel biomaterials: Decontamination of toxic metals from wastewater. Springer-Verlag. ISBN 978-3642-11329-1. 2010;23-26.

11. Vallero DA, Letcher TM. Unravelling environmental disasters. Elsevier; 2013.

12. Sabine M, Wendy G. Centre for hazardous substances research. Kansas University. U.S.; 2009.

13. Davidson PW, Myers GJ, Weiss B. Mercury exposure and child development outcomes. Pediatrics. 2004;113:1023-9.

14. Emsley J. Nature's building blocks. Oxford University Press. ISBN 9780199605637. 2011;34.

15. Stilwell S. Power, honour and shame: The ideology of royal slavery in the Sokoto Caliphate. Africa. Journal of the International African Institute (Edinburgh University Press). 2000;70(3):394-421.

16. AOAC. Official methods of analysis, association of analytical chemists. Washington DC, 15 Edition. 2005;11-14.

17. Liu WH, Zhao JZ, Soderlund L, Liu GH. Impacts of sewage irrigation on heavy metal distribution and contamination in Beijing, China. Environment International Journal. 2005;31:313-812.

18. Wang ST. Study on predicting effects of the soil polluted with heavy metals on vegetables and method of assessing quality of the soil in vegetable plot irrigated with a sewage-a case study on Baoding suburb. Agricultural University of Hebei, China. 2005;1-43.

19. USEPA, IRIS. United State, environmental protection agency, integrated risk information system; 2002.

Available:http://www.epa.gov/iris/subs (Accessed 25 February 2010)

20. International Standard Tolerable Limits. Maximum levels of heavy metals in soil and foods. ISBN 9780123970268; 2001.

21. Schumacher M, Bosgue MA, Domingo JL, Corbella J. Dietary intake of lead and calcium from foods in Tarragora Province, Spain. Bull Environ Contaminants and Toxicology. 1991;46:320-328.

22. Pirzada H, Ahmad SS, Rashid A, Shah $T$. Multivariate analysis of selected roadside plants (Dalbergia sissoo and Cannabis sativa) for lead pollution monitoring. Pakistan Journal Bot. 2009;41:17291736.

23. Peter BW. Municipal solid waste compositing: Potential effect of heavy metals in municipal solid waste composts on plants and environment. Boyce Thompson Institute for Plant Research at Cornell University. 2005;1-5.

24. Somers E. The toxic potential of trace metals in foods. A review. Journal of Food Science. 1983;39:215-217.

25. Lynch E, Braithwaite R. A review of the clinical and toxicological aspects of traditional (Herbal) medicines adulterated with heavy metals. Sand Well and West Birmingham Nhs. In: UK Trust Regional Laboratory for Toxicology City Hospital Birmingham UK. 2005;769-778.

26. Alabdulaaly Al, Khan MA. Heavy metals in cooler waters in Riyadh, Saudi Arabia. Environmental Monitoring and Assessment. 2009;157:23-28.

27. Zhan-Jun $X$, Shu-Qing L, Yan-Ling L, Yong-Lu Y. Health risk assessment of heavy metals for edible parts of vegetables grown in sewage-irrigated soils in suburbs of Baoding City, China. Environmental Monitoring Assess. 2012;184:3503-3513.

28. World Health Organization (WHO). Exposure to mercury: A major public health concern. Geneva, Switzerland, World Health Organization; 2007.

Available:http://www.who.int/phe/news/Mer cury-flyer.pdf

(Accessed 10 May 2010)

29. Al-Saleh I, Shinwari N. Report on the levels of cadmium, lead and mercury in imported rice grain samples. Biol Trace Elements Health Research. 2001;83(1):9196.

(c) 2019 Alhassan et al.; This is an Open Access article distributed under the terms of the Creative Commons Attribution License (http://creativecommons.org/licenses/by/4.0), which permits unrestricted use, distribution, and reproduction in any medium, provided the original work is properly cited.

Peer-review history:

The peer review history for this paper can be accessed here: http://www.sdiarticle3.com/review-history/47950 